\title{
FENOMENA PERNIAGAAN TEROKA BAHARU WANITA: JUSTIFIKASI LITERATUR TERHADAP PROSES PEMBINAAN TEORI KEUSAHAWANAN WANITA
}

\author{
NURUL AMIRA OMAR * \\ AHMAD FIRDAUSE MD FADZIL ** \\ ROSFATIHAH CHE MAT *** \\ amiraomar91@gmail.com*, firdause@unisza.edu.my**, fatihah29@gmail.com**
}

\begin{abstract}
Abstrak
Fenomena kemunculan perniagaan teroka baharu oleh wanita bukanlah topik baru jika disusuri dari susur galur sorotan kajian lepas. Ramai penyelidik lepas melihat pelbagai perspektif yang berbezabeza mengikut cabang disiplin masing-masing sepertimana ekonomi, pengurusan, psikologi, sosiologi dan lain-lain lagi. Namun ironinya, perbincangan berkaitan proses pembinaan teori keusahawanan wanita dikatakan masih bersifat pramatang. Kajian konseptual ini telah menggunakan kaedah kajian perpustakaan terhadap 95 artikel terpilih bersangkutan fenomena keusahawanan wanita dalam proses penciptaan teroka baharu yang terdiri daripada beberapa jurnal utama bidang keusahawanan wanita. Hasil kajian literatur ini mendapati, penglibatan usahawan wanita melalui perniagaan teroka baharu terbukti memberi impak positif dari sudut peningkatan peluang pekerjaan serta memperkembangkan inovasi produk baru dalam sesebuah negara. Kesinambungannya, kajian ini bertujuan untuk mendalami berkenaan fenomena keusahawanan wanita terutama berkenaan proses penciptaan teroka baharu memandangkan disiplin ini masih lagi bersifat pramatang terutama dalam proses pembangunan teori. Bersandarkan kepada teori Gartner, 1985, penyelidik memberi huraian yang jelas bagi menerangkan bagaimana keusahawanan wanita yang berlaku boleh dikaitkan dengan empat perspektif berbeza iaitu individu, persekitaran, organisasi yang ditubuhkan dan juga proses keusahawanan yang berlaku. Hasil huraian ini memberi gambaran dan sudut pandang yang khusus kepada usahawan wanita untuk memfokuskan kepada sisi yang memberi impak baik kepada perkembangan perniagaan teroka baru mereka.
\end{abstract}

Kata kunci: Keusahawanan, Keusahawanan Wanita, Proses Penciptaan Teroka Baharu, Psikologi, Sosiologi.

*** Pensyarah di Fakulti Perniagaan dan Pengurusan, Universiti Teknologi Mara, Malaysia. 


\title{
WOMEN'S NEW VENTURE PHENOMENON: A LITERATURE JUSTIFICATION FOR THE DEVELOPMENT PROCESS OF WOMEN ENTREPRENEURSHIP THEORY
}

\author{
NURUL AMIRA OMAR * \\ AHMAD FIRDAUSE MD FADZIL ** \\ ROSFATIHAH CHE MAT *** \\ amiraomar91@gmail.com*, firdause@unisza.edu.my**, fatihah29@gmail.com**
}

\begin{abstract}
The discussion about emerging women's new venture creation is not a new topic when traced back from the past literature. Previous researchers looked at various perspectives according to their respective disciplines, such as economics, management, psychology, sociology etc. Ironically, the discussion related to the women entrepreneurship theory-building process is said to be premature. This conceptual study has used the library research method on 95 selected articles concerning the phenomenon of women entrepreneurship in the new venture creation process consisting of several main women entrepreneurship journals. Based on the result from literature review, the involvement of women entrepreneurs through new venture businesses proved to have a positive impact in terms of employment opportunities and the development of new product innovations in a country. This study investigated the relevance of the women entrepreneurship phenomenon related to the new venture creation process as this discipline is still premature. Based on Gartner's theory, the researchers provide a clear description of how women's entrepreneurs can be associated with four different perspectives: individuals, environments, organizations established, and entrepreneurial process. The results of this description can provide a specific overview and perspective for women entrepreneurs to focus on the side that has a positive impact on the development of their new venture business.
\end{abstract}

Keywords: Entrepreneurship, Women Entrepreneurship, New Venture Creation Process, Psychology, Sociology.

* Undergraduate Student at Faculty of Business and Management, Universiti Sultan Zainal Abidin, Malaysia

** Senior Lecturer at Faculty of Business and Management, Universiti Sultan Zainal Abidin, Malaysia

*** Lecturer at Faculty of Business and Management,Universiti Teknologi Mara, Malaysia 


\subsection{Pengenalan}

Kajian berkenaan keusahawanan mempunyai pelbagai pendekatan berbeza terutama berkaitan konsep dan perspektif mengenai keusahawanan. Merujuk Deraman et al. (2010), bidang keusahawanan merupakan satu bidang baharu berbanding bidang lain seperti ekonomi, psikologi dan sosiologi. Walaupun terdapat perbezaan pandangan oleh penyelidik namun matlamatnya masih sama iaitu untuk merungkas di sebalik fenomena keusahawanan yang berlaku. Fokus utama diberikan oleh penyelidik lepas bagi merungkas bagi menjawab persoalan bagaimana fenomena keusahawanan ini berlaku adalah bersandarkan kepada bidang masing-masing. Merujuk Davidsson (2004, p. 1) menjelaskan fenomena keusahawanan adalah sering dikaitkan kepada beberapa perspektif berbeza iaitu kemasukan baharu (Lumpkin dan Dess, 1996), penciptaan perusahaan baharu (Low dan MacMillan, 1988), penciptaan teroka baharu (Gartner, 1988) dan proses penciptaan sesuatu kepada satu nilai yang berbeza (Hisrich dan Peters, 1989).

Kajian ini telah memberikan fokus khusus kepada proses penciptaan teroka baharu yang berlaku iaitu proses dilakukan oleh usahawan untuk merealisasikan sesebuah organisasi daripada idea menjadi satu organisasi yang nyata (Md Fadzil, 2016).Secara umumnya, proses penciptaan teroka baharu yang berlaku adalah merujuk bagaimana individu memperoleh idea keusahawanan, membuat bayangan perniagaan yang ditubuhkan, mencari pelaburan awal bertujuan merealisasikan perniagaan tersebut dan akhirnya legitimasi bersandarkan bayangan idea mereka (Alvarez dan Barney, 2007; McMullen dan Shepherd, 2006). Berdasarkan Gartner (1985); Hallieyana Sha'ari et al. (2019) menjelaskan proses keusahawanan berlaku adalah bersangkutan tindakan individu bagi merealisasikan sesuatu perniagaan manakala Shane and Venkataraman (2000) pula mengaitkan proses keusahawanan adalah merujuk terhadap bagaimana proses produk baharu dihasilkan. Walaupun wujud perbezaan pandangan tersebut, kedua-dua penyelidik berkongsi pandangan yang sama mengenai proses keusahawanan berlaku iaitu melibatkan proses eksploitasi bagi menghasilkan sesuatu produk (Md Fadzil, 2016).

Berdasarkan sorotan kajian lepas, fenomena keusahawanan sering dikaitkan dengan beberapa perspektif yang berbeza antaranya seperti psikologi (Baron, 2004; Gatewood et al., 1995; Md Fadzil et al., 2017; Sexton dan Bowman-Upton, 1990), persekitaran (Kolvereid et al., 1993; Md Fadzil, 2016; Shane dan Venkataraman, 2000) dan organisasi ditubuhkan (Kalleberg dan Leicht, 1991; Md Fadzil et al., 2017; Watson, 2002) yang mendorong terhadap fenomena keusahawanan berlaku. Perspektif psikologi telah mengaitkan penglibatan individu dalam keusahawanan adalah kerana telah di pacu oleh beberapa faktor yang berbeza seperti pengalaman individu, pengalaman kerja lepas dan latar belakang keluarga yang terlibat dalam perniagaan. Berbeza pula bagi perspektif persekitaran telah mengaitkan faktor luaran individu seperti kelompok sosial, ekonomi dan suntikan bagi melakukan aktiviti keusahawanan oleh kerajaan yang mendorong terhadap penglibatan individu dalam keusahawanan. Namun bagi perspektif organisasi pula menghuraikan penglibatan individu dalam keusahawanan adalah di pengaruhi oleh elemen dalam organisasi itu sendiri. Elemen organisasi adalah seperti perniagaan kekeluargaan dan kelebihan yang dimiliki oleh organisasi yang ditubuhkan telah mempengaruhi individu untuk terlibat dalam keusahawanan.

Walau bagaimanapun, kajian yang sedia ada hanya membincangkan fenomena yang 
berlaku secara satu dimensi berbanding melihat fenomena yang berlaku secara keseluruhan (Gartner, 1985; Jamil et al., 2020; Waqar et al., 2020). Oleh kerana kajian keusahawanan wanita masih di tahap pramatang, penyelidik telah memberikan huraian bersandarkan teori Gartner (1985) berkenaan proses penciptaan teroka baharu dipengaruhi oleh empat komponen yang berbeza iaitu psikologi individu, persekitaran, organisasi ditubuhkan dan proses keusahawanan. Maka, melalui perbincangan khusus terhadap keseluruhan dimensi akan memberi sumbangan ilmu dalam bidang keusahawan wanita. Seterusnya, kajian terhadap sorotan kajian lepas bertujuan menghuraikan secara jelas berkenaan fenomena keusahawanan wanita yang mana telah berevolusi dari masa ke masa.

\subsection{Kajian Literatur Terhadap Fenomena Keusahawanan Wanita}

Kajian berkenaan keusahawanan wanita turut berjaya menarik minat penyelidik lepas yang mana penglibatan wanita dalam keusahawanan telah dibincangkan bermula semenjak abad ke-19 lagi (Aziz dan Khan, 2015; Zainol Noor, 2018). Penyelidik lepas telah mula memberikan perhatian terhadap penglibatan wanita dalam keusahawanan kerana sumbangan wanita yang signifikan bagi ekonomi negara seperti penciptaan peluang pekerjaan dan inovasi produk setanding dengan penglibatan lelaki (Hallieyana Sha'ari et al., 2019). Namun sama seperti model keusahawanan, kajian keusahawanan wanita turut mengalami nasib yang sama iaitu model yang sedia ada masih kurang komprehensif disebabkan pandangan secara satu dimensi sahaja. Secara kasarnya kajian terhadap keusahawanan wanita tidak mempunyai perbezaan ketara yang mana telah mengaitkan perbezaan motivasi (Birley, 1989), pengalaman yang di miliki (Brush dan Hisrich, 1991) dan faktor jantina (Bird dan Brush, 2002) sebagai faktor yang mempengaruhi penglibatan wanita dalam keusahawanan.

Apa yang lebih menarik minat penyelidik untuk mendalami mengenai faktor pendorong penglibatan wanita adalah apabila terdapat keunikan yang mengaitkan terhadap faktor keluarga dan penerimaan sosial. Bersandarkan faktor keluarga, penglibatan wanita adalah bersangkutan terhadap keinginan mereka untuk perolehan pendapatan menyara keluarga (Lenka, 2017) dan keseimbangan masa kerja-keluarga (Shastri, 2019). Selain itu, penerimaan sosial turut menunjukkan faktor pendorong yang kritikal berdasarkan sorotan kajian lepas yang mana sering di lihat dari perspektif penerimaan sosial terhadap penglibatan wanita. Penerimaan yang dinyatakan adalah merujuk terhadap diskriminasi jantina yang mana mengaitkan terhadap cabaran di lalui oleh usahawan wanita (Sexton dan Bowman-Upton, 1990). Di antara cabaran yang di nyatakan adalah seperti persekitaran sosial tidak menerima penglibatan wanita kerana mengandaikan penglibatan mereka secara tidak serius (Boz dan Ergeneli, 2014; Buttner dan Rosen, 1989; Loscocco et al., 1991; Watson, 2002) dan beranggapan aktiviti keusahawanan adalah satu aktiviti maskulin (Bird dan Brush, 2002; Cole dan Mehran, 2018).

Rentetan daripada transformasi terhadap kajian keusahawanan wanita yang berlaku telah memberikan impak positif yang mana terdapat cabang baharu yang muncul bagi menjelaskan bagaimana fenomena keusahawanan wanita berlaku. Cabang baharu tersebut adalah merujuk perspektif feminis bagi menghuraikan berkenaan bagaimana keusahawanan wanita berlaku (Greer dan Greene, 2003). Di antara perspektif feminis berkaitan adalah seperti feminisme liberal, feminisme marxis dan feminisme radikal. 
Feminisme liberal adalah bersangkutan pandangan sosial terhadap penglibatan wanita dalam keusahawanan sebagai satu tindakan yang tidak sesuai, manakala feminisme marxis mengenai keinginan wanita untuk memperoleh pendapatan yang setimpal dengan pekerjaan yang mereka lakukan dan yang terakhir feminisme radikal merujuk perbezaan cabaran di antara usahawan lelaki dan wanita. Memandangkan kajian lepas hanya bersandarkan satu perspektif sahaja, Gartner (1985) menjelaskan penglibatan individu dalam keusahawanan adalah secara multi-dimensi iaitu secara berhubungan daripada pelbagai perspektif yang berbeza-beza. Pandangan sama turut diraikan Brush (1992) apabila menggunakan model oleh Gartner (1985) sebagai landasan teori terhadap kajian berkenaan keusahawanan wanita.

Walau bagaimanapun, satu kajian yang baharu perlu dilakukan bagi menjelaskan secara lebih mendalam berkenaan proses penciptaan teroka baharu bagi perspektif keusahawanan wanita. Ini kerana, cadangan (Brush, 1992) adalah pada tiga dekad lepas yang mana kajian keusahawanan wanita telah berkembang mengikut perubahan masa. Antara perubahan yang ketara adalah yang mana pada masa kini penciptaan teroka baharu lebih diterokai antaranya melalui e-dagang, perniagaan sosial dan perniagaan kekeluargaan (Jamil et al., 2020; Md Fadzil, 2017; Waqar et al., 2020). Oleh itu, motivasi kajian konseptual ini adalah mendalami berkenaan proses penciptaan teroka baharu di kalangan usahawan wanita bersandarkan model Gartner (1985) yang melibatkan empat elemen utama seperti psikologi individu, persekitaran, organisasi dan proses keusahawanan.

\subsection{Metodologi Kajian}

Kajian konseptual ini dirangka bersandarkan model Gartner (1985) yang mana terdapat empat komponen utama yang mempengaruhi penglibatan usahawan dalam proses penciptaan teroka baharu iaitu psikologi individu, persekitaran, organisasi yang ditubuhkan dan proses keusahawanan yang mana saling berinteraksi di antara satu sama lain. Oleh itu, bersandarkan model Gartner (1985) penyelidik telah menghuraikan berkenaan faktor-faktor yang boleh dikaitkan dengan penglibatan wanita dalam keusahawanan. Kajian ini telah melibatkan 95 artikel kajian perpustakaan yang berkaitan proses penciptaan teroka baharu dan keusahawanan wanita oleh penyelidik lepas yang terdiri daripada beberapa jurnal diiktiraf di peringkat antarabangsa antaranya seperti Journal of Small Business Management, Research on Women Business Owners, Academy of Management Review and Entrepreneurship Theory and Practice. Kesemua jurnal ini dipilih merupakan antara jurnal utama yang menjadi rujukan akademik bagi bidang keusahawanan wanita

\subsection{Landasan Teori Keusahawanan Wanita}

Bersandarkan landasan teori oleh Gartner (1985), terdapat beberapa komponen yang mempengaruhi kepada proses penciptaan teroka baharu. Komponen-komponen tersebut ialah psikologi individu, persekitaran, organisasi dan proses keusahawanan yang berlaku. Pada Rajah 1 menunjukkan komponen-komponen yang mempengaruhi kepada proses penciptaan teroka baharu. 


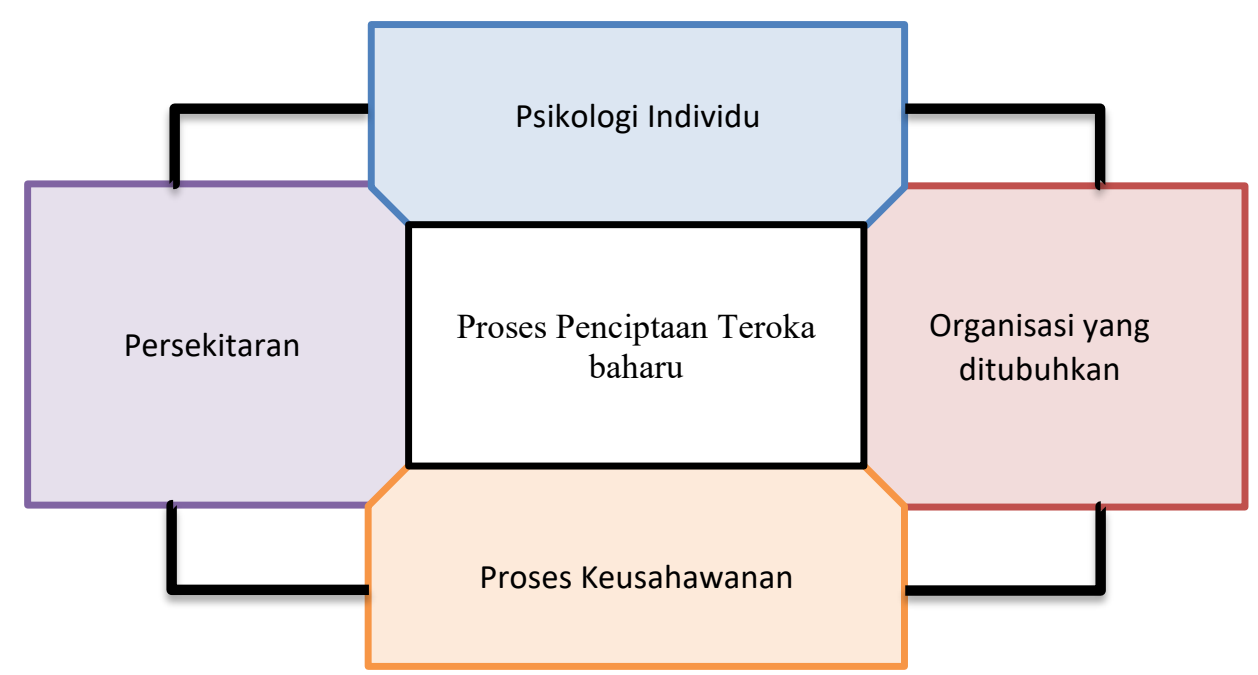

Rajah 1: Teori berkenaan proses penciptaan teroka baharu oleh Gartner (1985)

\subsection{Psikologi Individu}

Perspektif psikologi merupakan faktor pendorong yang terbit daripada dalaman individu. Faktor pendorong secara dalaman ini telah mempengaruhi pembuatan keputusan individu (Shane, 2003) yang mana membezakan di antara usahawan dan bukan usahawan sepertimana dijelaskan oleh Gartner (1985). Di antara faktor yang sering mempengaruhi pembuatan keputusan individu adalah seperti pengalaman individu, latar belakang usahawan dan sifat yang ada pada individu (Kirkley, 2016; Md Fadzil, 2016; Md Fadzil et al., 2019; Shane, 2003; Shaver dan Scott, 1991). Merujuk Davidsson and Gordon (2012), proses penciptaan teroka baharu telah dipengaruhi oleh faktor dalaman individu seperti pengalaman, sifat dan motivasi. Isu sama turut dibincangkan berkenaan keusahawanan wanita berkenaan faktor pendorong yang mempengaruhi pembuatan keputusan seseorang wanita. Namun, terdapat sedikit perbezaan apabila motivasi usahawan wanita terlibat dalam aktiviti keusahawanan sering berkaitan faktor keluarga, sifat individu dan keinginan diperoleh bagi menyara keluarga (Birley, 1989; Gatewood et al., 1995; Maden, 2015; Orhan dan Scott, 2001; Sharafizad, 2016). Oleh itu, terdapat tiga faktor utama yang boleh dikaitkan penglibatan wanita dalam keusahawanan iaitu kognitif, motivasi dan personaliti.

\subsubsection{Kognitif}

Faktor kognitif telah mempengaruhi tindakan individu secara langsung kerana dikaitkan terhadap bagaimana pemikiran individu dalam memproses sesuatu maklumat berkenaan keusahawanan. Pemikiran individu berfungsi sebagai tempat penyimpanan maklumat, mempengaruhi penggunaan bahasa dan penggunaan simbol oleh seseorang individu (Baron, 1998; Barsalou, 1992). Faktor kognitif yang dimiliki oleh setiap individu adalah berbeza kerana dipengaruhi oleh konsep yang berbeza seperti pengalaman kerja lepas, latar belakang keluarga yang terlibat dalam perniagaan dan latar belakang individu (Fatoki dan Oni, 2015; Roundy et al., 2018; Shapero 
dan Sokol, 1982).

Bagi kajian keusahawanan wanita pula turut mengaitkan faktor kognitif dalam pembuatan keputusan individu untuk terlibat dalam proses penciptaan teroka baharu. Berdasarkan sorotan kajian lepas mengenai keusahawanan wanita, sering kali mengaitkan penglibatan wanita adalah dipengaruhi oleh pengalaman individu, pengalaman kerja lepas dan peranan keluarga yang turut terlibat dalam perniagaan. Oleh itu berdasarkan sorotan kajian lepas, peranan kognitif telah memacu penglibatan wanita dalam keusahawanan adalah dipengaruhi oleh keinginan mereka untuk memenuhi keinginan mereka seperti perolehan pendapatan tambahan dan fleksibiliti dalam waktu bekerja (Hallieyana Sha'ari et al., 2019; Muhamad Amirul Rifqi Mohd Hamdan dan Mohammad Mujaheed Hassan, 2018; Nor Aini Idris, 2003).

\subsubsection{Motivasi}

Perspektif psikologi turut mengaitkan faktor motivasi sama ada bertujuan memperoleh kepuasan diri ataupun perolehan dorongan di luar individu telah menggalakkan aktiviti keusahawanan berlaku (Md Fadzil, 2016; Shane, 2003). Merujuk kepada Sundin and Holmquist (2006) telah menjelaskan faktor motivasi mempunyai dua sub yang berbeza iaitu motivasi dalaman dan luaran. Motivasi dalaman merujuk tindakan individu bertujuan untuk memenuhi kepuasan diri tanpa melibatkan perolehan sebarang ganjaran. Namun berbeza pula bagi motivasi luaran, tindakan mereka bertujuan untuk perolehan ganjaran seperti wang ataupun memenuhi kepuasan orang di persekitaran mereka (Adomako et al., 2016; Thapa, 2015).

Kajian keusahawanan wanita telah mendapati terdapat beberapa faktor dalaman mendorong penglibatan wanita dalam keusahawanan seperti minat dan pencapaian matlamat (McGowan et al., 2012; Modarresi et al., 2016; Shastri, 2019). Bagi faktor luaran pula penglibatan wanita dalam keusahawanan sering dikaitkan dengan fleksibiliti dalam waktu bekerja dan memperoleh pendapatan tambahan. Keinginan wanita memperoleh keduadua komponen ini bagi memenuhi kepuasan diri bagi waktu bekerja dan keluarga yang seimbang, manakala memperoleh pendapatan tambahan bertujuan untuk keluar dari kemiskinan ataupun untuk meningkatkan kuasa membeli bagi keluarga mereka (Hallieyana Sha'ari et al., 2019; Nor Aini Idris, 2003). Walau bagaimanapun sejak kebelakangan ini, penyelidik mendapati motivasi luaran usahawan wanita turut sama dipacu oleh persekitaran individu seperti perniagaan sosial. Melalui penubuhan perniagaan sosial yang ditubuhkan usahawan wanita bukan hanya mampu untuk memenuhi keperluan diri tetapi keinginan mereka untuk memberikan sumbangan terhadap persekitaran mereka (Lenka, 2017; Orhan dan Scott, 2001; Solesvik, 2019). 


\subsubsection{Personaliti}

Selain faktor motivasi, personaliti individu turut mempengaruhi kepada proses penciptaan teroka baharu memandangkan setiap individu mempunyai perbezaan personaliti iaitu usahawan dan bukan usahawan. Menurut Gartner (1985) perbezaan ini wujud dipengaruhi latar belakang seseorang individu. Perkara ini telah mendorong pembentukan personaliti berbeza-beza dan secara langsung mempengaruhi tindakan setiap individu (Cloninger, 2008; Md Fadzil et al., 2018).

Penglibatan wanita dalam keusahawanan turut dikaitkan dengan personaliti dimiliki seperti keinginan autonomi, pengambilan risiko dan pencapaian matlamat yang tinggi (Abdul Mutalib et al., 2015; Loscocco et al., 1991; Maden, 2015; Tanusia et al., 2016; Watson, 2002). Walaupun personaliti dikatakan sebagai pendorong terhadap penglibatan wanita dalam aktiviti keusahawanan, namun wujud perbezaan pandangan berkenaan keusahawanan wanita iaitu tindakan usahawan wanita tersebut adalah lebih bersifat feminis. Sifat feminis usahawan wanita ini memberikan impak lebih kecil berbanding daripada usahawan lelaki (Bernardino et al., 2018; Bird dan Brush, 2002). Selain itu, kajian terbaharu mendapati penglibatan wanita turut dipengaruhi oleh personaliti mereka yang bersifat altruistik iaitu cenderung untuk memberikan keuntungan terhadap persekitaran berbanding memenuhi keperluan diri (Hechavarría dan Welter, 2015; Sundin dan Holmquist, 2006; Zisser et al., 2019).

\subsection{Persekitaran}

Selain melihat perspektif psikologi individu sebagai pendorong penglibatan individu dalam proses penciptaan teroka baharu, perspektif persekitaran turut dikenal pasti mempengaruhi aktiviti keusahawanan yang berlaku. Berdasarkan kajian lepas, penglibatan usahawan adalah di pengaruhi oleh beberapa faktor seperti perolehan sumber yang mudah, kemudahan melakukan aktiviti keusahawanan dan sokongan yang diperoleh daripada persekitaran (Edelman dan Yli-Renko, 2010; Md Fadzil, 2017). Bersandarkan kepada perspektif persekitaran turut mendapati tindakan usahawan terlibat dalam aktiviti keusahawanan adalah bertujuan untuk memenuhi keperluan permintaan pasaran ataupun disebabkan kelompangan pasaran yang wujud (Drucker, 1985; Shane dan Venkataraman, 2000; Talib et al., 2017). Oleh itu, terdapat tiga faktor besar boleh dikaitkan sebagai pendorong terhadap penglibatan wanita dalam aktiviti keusahawanan seperti politik, ekonomi dan sosial.

\subsubsection{Politik}

Berdasarkan kajian lepas mendapati campur tangan pihak kerajaan ataupun agensi bukan kerajaan turut menjadi pemacu kepada aktiviti keusahawanan berlaku (Md Fadzil, 2016). Campur tangan kerajaan seperti penyediaan kemudahan kepada aktiviti keusahawanan telah mendorong terhadap penglibatan individu antaranya seperti bantuan kewangan, bantuan berbentuk fizikal ataupun pembentukan dasar (Gatewood et al., 
1995; Md Fadzil, 2017; Shane, 2003).

Hasil kajian yang memfokuskan kepada keusahawanan wanita mendapati terdapat beberapa kajian bersangkutan bantuan kerajaan tidak hanya wujud dalam bentuk kewangan, bantuan fizikal malahan terdapat beberapa program susulan yang dilaksanakan bagi menggalakkan penglibatan wanita. Di antara program-program disediakan adalah seperti penyediaan kelas kemahiran komunikasi, teknologi dan bimbingan perniagaan usahawan wanita dan penggubalan dasar yang bersesuaian bagi usahawan wanita bagi mewujudkan keupayaan persaingan di kalangan usahawan wanita (Arshad et al., 2015; Hoe et al., 2012; Hussin, 2002; Rusli, 2017; Talib et al., 2017). Tindakan tersebut dilaksanakan memandangkan aktiviti keusahawanan wanita sering cenderung tidak memperoleh pengiktirafan setimpal berbanding usahawan lelaki (Al Mamun et al., 2016).

\subsubsection{Ekonomi}

Seterusnya faktor ekonomi yang dikatakan mempengaruhi fenomena keusahawanan berlaku. Merujuk kepada Baumol (1996) menjelaskan keadaan ekonomi sama ada produktif ataupun tidak produktif memberikan impak besar terhadap aktiviti keusahawanan. Hal ini kerana ekonomi yang produktif mempengaruhi individu berinovasi dalam pengenalpastian peluang terhadap perkembangan ekonomi di sesebuah negara (FatimahSalwa et al., 2013; Palalic et al., 2017; Shane, 2003). Menurut Hallieyana Sha'ari et al. (2019) menjelaskan perkembangan ekonomi yang positif mempengaruhi terhadap peningkatan penglibatan wanita dalam keusahawanan. Penglibatan wanita sedikit sebanyak dipengaruhi oleh ekonomi produktif kerana mempunyai potensi kemunculan peluang baharu lebih tinggi berbanding situasi ekonomi yang tidak produktif (Nurdin et al., 2017; Talib et al., 2017).

\subsubsection{Sosial}

Faktor sosial adalah berkenaan bagaimana seseorang individu berinteraksi dan menjalinkan hubungan dengan persekitaran mereka semasa melaksanakan aktiviti keusahawanan (Man et al., 2002). Merujuk kepada kajian lepas, persekitaran sosial sering dikaitkan dengan sokongan dan dorongan yang diperoleh oleh usahawan yang mana telah mendorong penglibatan mereka dalam keusahawanan. Sokongan yang diperoleh ini hadir sama ada perkara yang mendorong tindakan individu untuk melakukan aktiviti keusahawanan ataupun sokongan dari segi bantuan kewangan dan penyampaian maklumat (Ezilda, 2017; Kaur dan Bains, 2013; Kothari, 2017; Shane, 2003).

Hakikat yang sama turut berlaku dalam keusahawanan wanita yang mana sokongan diperoleh adalah sebagai pendorong utama terhadap penglibatan wanita dalam keusahawanan (Birley, 1989; Renzulli et al., 2000). Walau bagaimanapun, terdapat penyelidik lepas mendapati bahawa faktor sosial 
tidak hanya melihat dari sokongan yang mendorong, namun beberapa faktor lain seperti pengaruh budaya, agama dan jalinan hubungan perniagaan di antara usahawan dan persekitarannya (Batjargal et al., 2019; Burt, 1998; Greguletz et al., 2019; Kungwansupaphan dan Leihaothabam, 2016).

\subsection{Organisasi yang ditubuhkan}

Perspektif organisasi yang ditubuhkan pula telah mengaitkan jenis atau kelebihan yang dimiliki oleh sesuatu perniagaan telah mempengaruhi penglibatan individu dalam aktiviti keusahawanan. Kelebihan dimiliki adalah merujuk kos penubuhan sesuatu perniagaan dan bersifat francais ataupun secara kerjasama (Gartner, 1985). Kajian lain oleh Steier (2007) menjelaskan faktor perniagaan kekeluargaan turut menyumbang penglibatan individu dalam keusahawanan. Hal sedemikian, melalui perniagaan kekeluargaan usahawan memperoleh beberapa kemudahan seperti bantuan kewangan, maklumat dan sumber (Hamilton et al., 2017; Zellweger et al., 2011). Namun bagi kajian terhadap keusahawanan wanita mendapati faktor organisasi yang ditubuhkan telah mempengaruhi penglibatan wanita bersandarkan kemahiran mereka dalam melakukan sesuatu aktiviti (Birley, 1989; Kang, 2011; Muhammad dan Abu, 2016). Bagi mendalami bagaimana penglibatan wanita dalam keusahawanan bersandarkan kemahiran yang dimiliki, terdapat beberapa kajian telah mengaitkan perniagaan berasaskan jantina yang mempunyai hubungan signifikan dengan kemahiran tertentu dimiliki (Hallieyana Sha'ari et al., 2019; Muhamad Amirul Rifqi Mohd Hamdan dan Mohammad Mujaheed Hassan, 2018). Perniagaan jantina merujuk sesuatu aktiviti perniagaan yang dilakukan sinonim dengan jantina individu seperti wanita; tudung dan kosmetik manakala lelaki; alatan sukan dan perkilangan.

\subsection{Proses Keusahawanan}

Berdasarkan Gartner (1985) proses keusahawanan merujuk tindakan individu dalam mengeksploitasi peluang keusahawanan. Tindakan usahawan adalah seperti proses pengumpulan sumber, perolehan sokongan perniagaan dan sebarang aktiviti semasa penubuhan sebuah perniagaan. Namun berbeza oleh Shane dan Venkataraman (2000) menjelaskan proses keusahawanan adalah merujuk kepada proses penemuan yang berlaku iaitu dua sub proses terlibat iaitu proses penemuan dan proses eksploitasi. Walau bagaimanapun kedua-dua pandangan tersebut bersetuju bahawa proses keusahawanan adalah berkaitan proses mengeksploitasi peluang keusahawanan yang muncul. Oleh itu, usahawan merupakan individu yang mampu mengenal pasti sesuatu peluang untuk melakukan aktiviti keusahawanan (Abu Bakar et al., 2007; Muhamad Amirul Rifqi Mohd Hamdan dan Mohammad Mujaheed Hassan, 2018).

\subsubsection{Proses Penemuan}

Proses penemuan adalah bersangkutan bayangan idea kepada aktiviti keusahawanan yang hendak dilakukan. Bayangan idea yang dilakukan bersandarkan perolehan maklumat yang mencukupi dan dieksploitasi 
peluang yang muncul bagi melalukan aktiviti keusahawanan. Bersandarkan proses penemuan, penyelidik lepas sering mengaitkan faktor kognitif dan persekitaran individu sebagai pemacu utama yang mendorong usahawan memperoleh bayangan idea bagi menubuhkan perniagaan baharu (Gartner, 1988; Shane dan Venkataraman, 2000; Sparrow dan Makram, 2015). Proses sama turut berlaku terhadap penglibatan wanita yang mana sering dikaitkan bersandarkan faktor kognitif dan faktor kekeluargaan yang mendorong penglibatan mereka dalam keusahawanan (Hallieyana Sha'ari et al., 2019; Ishak et al., 2011).

\subsubsection{Proses Eksploitasi}

Bagi proses eksploitasi adalah tindakan ataupun aktiviti yang dilakukan oleh usahawan bagi merealisasikan bayangan idea menjadi satu sati entiti perniagaan yang nyata (Gartner, 1985; Shane dan Venkataraman, 2000). Aktiviti-aktiviti yang dilakukan adalah merujuk kepada bagaimana usahawan mengeksploitasi peluang yang muncul seperti mendapatkan sokongan daripada pelanggan dan pembekal, perolehan sumber dan aktiviti lain bagi meningkatkan kemahiran keusahawanan (Abu Bakar et al., 2007; Nor Aini Idris, 2003). Aktiviti keusahawanan yang berlaku adalah di pengaruhi oleh beberapa faktor lain seperti persekitaran, personaliti dan ekonomi. Walau bagaimanapun aktiviti keusahawanan adalah bertujuan untuk merealisasikan bayangan idea yang dikenal pasti sebagai pendorong utama terhadap tindakan individu (Cai dan Liu, 2007; Palalic et al., 2017; Park, 2017; Sirmon et al., 2008).

\subsection{Kesimpulan}

Kesimpulan terhadap sorotan kajian lepas mendapati jurang perbezaan di antara kajian keusahawanan wanita, yang mana memerlukan kajian secara mendalam. Sejajar dengan arus globalisasi kini, penglibatan wanita secara amnya dalam sektor buruh semakin meningkat berbanding beberapa tahun kebelakangan lalu terutama melibatkan bidang keusahawanan. Komponen-komponen yang telah dibincangkan dalam kajian ini menjelaskan faktor yang mempengaruhi tindakan usahawan wanita yang terlibat dalam proses penciptaan teroka baharu. Oleh itu, kajian secara empirikal perlu dilakukan bagi kegunaan pihak kerajaan, pihak akademik, penggubal polisi dan pihak berkaitan bagi tujuan mempengaruhi penglibatan wanita dalam keusahawanan dalam usaha meningkatkan ekonomi negara.

\subsection{Penghargaan}

Kajian ini telah mendapat tajaan daripada Kementerian Pendidikan Malaysia di bawah Skim Geran Penyelidikan asas (FRGS) no. FRGS/1/2018/SS03/UNISZA/02/03. Penyelidik mengucapkan jutaan terima kasih kepada Universiti Sultan Zainal Abidin. 


\section{Rujukan}

Abdul Mutalib, R., Arshad, R., Ismail, N. S. A., dan Ahmad, Z. (2015). Women and entrepreneurship: An overview of women entrepreneurship programs in Malaysia. Journal of Governance and Development, 11, 15-14.

Abu Bakar, T. S., Ali, A. M., Omar, R., Som, H. M., dan Muktar, S. N. (2007). Penglibatan kaum wanita dalam aktiviti keusahawanan di negeri Johor: Kajian terhadap faktor-faktor kritikal kejayaan dan kegagalan pengendalian perniagaan Universiti Teknologi Malaysia].

Adomako, S., Danso, A., Uddin, M., dan Damoah, J. O. (2016). Entrepreneurs' optimism, cognitive style and persistence. International Journal of Entrepreneurial Behavior dan Research, 22(1), 84-108.

Al Mamun, A., Muniady, R., Yukthamarani, P. P., Noor Raihani Binti, Z., dan Mohamad, M. R. (2016). Micro-enterprise development initiatives and entrepreneurial competencies, innovativeness, and social capital in Malaysia. Development in Practice, 26(8), 1094-1110.

Alvarez, S. A., dan Barney, J. B. (2007). Discovery and creation: Alternative theories of entrepreneurial action. Strategic Entrepreneurship Journal, 1(1-2), 11-26.

Arshad, R., Ahmad, Z., Abdul Mutalib, R., dan Ismail, N. S. A. (2015). A Survey of Women Entrepreneurship in Malaysia: A case of Siti Khadijah Market, Kelantan and Pekan Rabu, Kedah. Journal of Government and Development, 11(Special Issue), 125-139.

Aziz, M. K., dan Khan, N. L. B. M. (2015). Regional course on statistics informality: Informal economy, work and employment.

Baron, R. A. (1998). Cognitive mechanisms in entrepreneurship: Why and when enterpreneurs think differently than other people. Journal of Business Venturing, 13(4), 275-294.

Baron, R. A. (2004). The cognitive perspective: a valuable tool for answering entrepreneurship's basic "why" questions. Journal of Business Venturing, 19(2), 221-239.

Barsalou, L. W. (1992). Frames, concepts, and conceptual fields. In Frames, fields, and contrasts: New essays in semantic and lexical organization. (pp. 21-74): Lawrence Erlbaum Associates, Inc.

Batjargal, B., Webb Justin, W., Tsui, A., Arregle, J.-L., Hitt Michael, A., dan Miller, T. (2019). The moderating influence of national culture on female and male entrepreneurs' social network size and new venture growth. Cross Cultural danamp; Strategic Management, 26(4), 490-521.

Baumol, W. J. (1996). Entrepreneurship: Productive, unproductive, and destructive. Journal of Business Venturing, 11(1), 3-22.

Bernardino, S., Freitas Santos, J., dan Cadima Ribeiro, J. (2018). Social entrepreneur and gender: What's personality got to do with it? International Journal of Gender and Entrepreneurship, 10(1), 61-82. 
Bird, B., dan Brush, C. (2002). A gendered perspective on organizational creation. Entrepreneurship Theory and Practice, 26(3), 41-65.

Birley, S. (1989). Female entrepreneurs: Are they really any different? In C. G. Brush, N. M. Carter, E. J. Gatewood, dan P. G. Greene (Eds.), Women and Entrepreneurship Contemporary Classics (Vol. 27, pp. 32-37). Edward Elgar Publishing.

Boz, A., dan Ergeneli, A. (2014). Women entrepreneurs' personality characteristics and parents' parenting style profile in Turkey. Procedia - Social and Behavioral Sciences, 109, 92-97.

Brush, C. G. (1992). Research on women business owners: Past trends, a new perspective and future directions. Entrepreneurship Theory and Practice, 16(4), 5-30.

Brush, C. G., dan Hisrich, R. D. (1991). Antecedent influences on women owned businesses. Journal of Managerial Psychology.

Burt, R. S. (1998). The gender of social capital. Rationality and Society, 10(1), 5-46.

Buttner, E. H., dan Rosen, B. (1989). Funding new business ventures: Are decision makers biased against women entrepreneurs? Journal of Business Venturing, 4(4), 249-261.

Cai, L., dan Liu, Q. (2007). The resource intrgration model in new ventures. Science of Science and Management of Science and Technology, 28(2), 95-102.

Cloninger, R. (2008). The psychobiological theory of temperament and character: Comment on farmer and goldberg. Psychological Assessment, 20, 292-299; discussion 300.

Cole, R. A., dan Mehran, H. (2018). Gender and the availability of credit to privately held firms: Evidence from the surveys of small business finances. Federal Reserve Bank of New York Staff Report(383).

Davidsson, P. (2004). Researching Entrepreneurship, . Springer. ISBN: 9780387257013.

Davidsson, P., dan Gordon, S. (2012). Panel studies of new venture creation: A methods-focused review and suggestions for future research. Small Business Economics, 39, 853-876.

Deraman, N., Mohamad, A., Bakar, H., Hashim, N., dan Ooi, Y. K. (2010). Keusahawanan: Teori dan praktis (2nd ed.). McGraw Hill Education.

Drucker, P. F. (1985). Innovation and entrepreneurship: Practice and principle. Routledge, 2012.

Edelman, L., dan Yli-Renko, H. (2010). The impact of environment and entrepreneurial perceptions on venture-creation efforts: Bridging the discovery and creation views of entrepreneurship. Entrepreneurship: Theory and Practice, 34(5), 833-856.

Ezilda, M. C. (2017). Factors affecting the success of women's entrepreneurship: A review of literature. International Journal of Gender and Entrepreneurship, 9(1), 31-65.

Fatimah-Salwa, A., Mohamad-Azahari, A., dan Joni-Tamkin, B. (2013). Success factors of 
successful microcredit entrepreneurs: Empirical evidence from Malaysia. International Journal of Business and Social Science, 4(5), 153-159.

Fatoki, O., dan Oni, O. A. (2015). The impact of entrepreneurial alertness on the performance of immigrant-owned enterprises in South Africa. Journal of Economics, 6(3), 219-225.

Gartner, W. B. (1985). A conceptual framework for describing the phenomenon of new venture creation. Academy of Management Review, 10(4).

Gartner, W. B. (1988). "Who is an entrepreneur?" Is the wrong question. American Journal of Small Business, 12(4), 11-32.

Gatewood, E. J., Shaver, K. G., dan Gartner, W. B. (1995). A longitudinal study of cognitive factors influencing start-up behaviors and success at venture creation. Journal of Business Venturing, 10(5), 371-391.

Greer, M. J., dan Greene, P. G. (2003). Feminist theory and the study of entrepreneurship. New Perspectives on Women Entrepreneurs, 1-24.

Greguletz, E., Diehl, M.-R., dan Kreutzer, K. (2019). Why women build less effective networks than men: The role of structural exclusion and personal hesitation. Human Relations, 72(7), 12341261.

Hallieyana Sha'ari, Hamid Auni Lukman, Maizatul Akhmar Mat Yusoff, dan Noor Amani Mohamed Hussin. (2019). Faktor pendorong penglibatan usahawan wanita dalam perniagaan. In N. Musa dan N. N. Amran (Eds.), Inspirasi Muslimah ke Arah Matlamat Pembangunan Mapan (Vol. 2, pp. 233-249). Persatuan Ulama' Malaysia.

Hamilton, E., Discua Cruz, A., dan Jack, S. (2017). Re-framing the status of narrative in family business research: Towards an understanding of families in business. Journal of Family Business Strategy, 8(1), 3-12.

Hechavarría, D. M., dan Welter, C. (2015). Opportunity types, social entrepreneurship and innovation: Evidence from the panel study of entrepreneurial dynamics [Article]. International Journal of Entrepreneurship and Innovation, 16(4), 237-251.

Hisrich, R. D., dan Peters, M. P. (1989). Entrepreneurship: Starting, developing, and managing a new enterprise. BPI, Irwin.

Hoe, C. H., Isa, F. M., Hin, C. W., Hashim, N., Yunus, J. M., dan Abdullah, H. H. (2012). Development of women entrepreneurs: The case of Malaysia. Political Science, 2(6).

Hussin, H. (2002). Cabaran dan halatuju usahawan wanita dalam era globalisasi. Kertas kerja Seminar Globalisasi dan Usahawan Wanita: Kepintaran, Emosi dan Integriti. Sintok, May 2931, 2002.

Ishak, Y., Khairunnisa, M., Zaimah, D., dan Mohd Shukri, H. (2011). Faktor keusahawanan dan prestasi kejayaan usahawan Melayu di Pulau Langkawi, Kedah. Prosiding PERKEM, Jilid 2, 196-207. 
Jamil, M., Waqar, A., Fadzil, A. F. M., dan Abidin, Z. (2020). Theoretical Process of Entrepreneurial Family: Developing the Conceptual Framework by using Strategic Entrepreneurship Approach for the Describing Business Sustainability.

Kalleberg, A. L., dan Leicht, K. T. (1991). Gender and organizational performance: Determinants of small business survival and success. Academy of Management Journal, 34(1), 136-161.

Kang, B. O. (2011). A study on the influence of CEO's entrepreneurship in SMEs on business performance: Franchise business. Graduate School of Chung Ang University, Doctoral Dissertation.

Kaur, H., dan Bains, A. (2013). Understanding the concept of entrepreneur competency. Journal of Business Management dan Social Sciences Research, 2(11), 31-33.

Kirkley, W. W. (2016). Creating ventures: Decision factors in new venture creation. Asia Pacific Journal of Innovation and Entrepreneurship, 10(1), 151-167.

Kolvereid, L., Shane, S., dan Westhead, P. (1993). Is it equally difficult for female entrepreneurs to start businesses in all countries? Journal of Small Business Management, 31(4), 42.

Kothari, T. (2017). Women entrepreneurs' path to building venture success: Lessons from India. South Asian Journal of Business Studies, 6(2), 118-141.

Kungwansupaphan, C., dan Leihaothabam, S. (2016). Capital factors and rural women entrepreneurship development: A perspective of Manipur state, India. Gender in Management: An International Journal, 31(3), 207-221.

Lenka, U. (2017). Role of women entrepreneurs and NGO's in promoting entrepreneurship: Case studies from Uttarakhand, India. Journal of Asia Business Studies, 11(4), 451-465.

Loscocco, K. A., Robinson, J., Hall, R. H., dan Allen, J. K. (1991). Gender and small business success: An inquiry into women's relative disadvantage. Social Forces, 70(1), 65-85.

Low, M. B., dan MacMillan, I. (1988). Entrepreneurship: Past research and future challenges (Vol. 14).

Lumpkin, G. T., dan Dess, G. G. (1996). Clarifying the entrepreneurial orientation construct and linking it to performance. Academy of Management Review, 21(1), 135-172.

Maden, C. (2015). A gendered lens on entrepreneurship: Women entrepreneurship in Turkey. Gender in Management: An International Journal, 30(4), 312-331.

Man, T. W., Lau, T., dan Chan, K. (2002). The competitiveness of small and medium enterprises: A conceptualization with focus on entrepreneurial competencies. Journal of Business Venturing, 17(2), 123-142.

McGowan, P., Redeker, C. L., Cooper, S. Y., dan Greenan, K. (2012). Female entrepreneurship and the management of business and domestic roles: Motivations, expectations and realities. Entrepreneurship dan Regional Development, 24(1-2), 53-72. 
McMullen, J. S., dan Shepherd, D. A. (2006). Entrepreneurial action and the role of uncertainty in the theory of the entreprenuer. In Academy of Management Review (Vol. 31).

Md Fadzil, A. F. (2016). Justifikasi kepada fenomena kemunculan perniagaan baharu: Tinjauan sorotan kajian lepas terhadap proses pembinaan teori keusahawanan. International Journal of Creative Future and Heritage, 4(2), 1-18.

Md Fadzil, A. F. (2017). Kajian penerokaan terhadap proses penciptaan perniagaan baharu EDagang di Malaysia. Doctoral Thesis, Faculty of Entrepreneurship and Business, Universiti Malaysia Kelantan.

Md Fadzil, A. F., Ghazali, P. L., Yaacob, M. R., dan Muhayiddin, M. N. (2018). The relation of entrepreneur cognition and personality: The determinant factors of e-commerce entrepreneurship involvement in Malaysia. International Journal Of Asian Social Sciences, 8(12), 1228-1235.

Md Fadzil, A. F., Hashim, U. J., Yaacob, M. R., Sallehudin, H., Muhayiddin, M. N., Mukhtar, D., dan Ibrahim, R. M. (2019). Entrepreneurial psychology and competencies: some perspectives from e-commerce entrepreneurs in Malaysia. Journal of Entrepreneurship, Business and Economics, 7(2), 31-79.

Md Fadzil, A. F., Yaacob, M. R., dan Muhayiddin, M. N. (2017). The roles of competencies in the new venture creation among e-Commerce entrepreneurs in Malaysia. International Journal of Business and Management Invention, 6(3), 25-31.

Modarresi, M., Arasti, Z., Talebi, K., dan Farasatkhah, M. (2016). Women's entrepreneurship in Iran: How are women owning and managing home-based businesses motivated to grow? International Journal of Gender and Entrepreneurship, 8(4), 446-470.

Muhamad Amirul Rifqi Mohd Hamdan, dan Mohammad Mujaheed Hassan. (2018). Faktor Penglibatan dan Cabaran Wanita Melayu dalam bidang Keusahawanan di Malaysia.

Muhammad, N., dan Abu, M. H. J. J. o. B. I. (2016). Faktor yang Mendorong Kejayaan Usahawan Perusahaan Kecil dan Sederhana (PKS) MARA di Daerah Melaka Tengah. Journal of Business Innovation, 1(2), 31.

Nor Aini Idris. (2003). Daya saing usahawan wanita Melayu menghadapi cabaran globalisasi. Prosiding Persidangan Kebangsaan Pusat Pengajian Sosial, Pembangunan dan Persekitaran, 12-13.

Nurdin, G., Chan, G. K., Selvadurai, S., dan Ishak, S. (2017). Hubungan sosial dan perniagaan kecil-kecilan di Malaysia-Tingkah laku inovatif usahawan wanita atas talian. GeografiaMalaysian Journal of Society and Space, 10(6).

Orhan, M., dan Scott, D. (2001). Why women enter into entrepreneurship: An explanatory model. Women in Management Review, 16(5), 232-247.

Palalic, R., Ramadani, V., dan Dana, L. P. (2017). Entrepreneurship in Bosnia and Herzegovina: Focus on gender. European Business Review, 29(4), 476-496. 
Park, C. (2017). A study on effect of entrepreneurship on entrepreneurial intention. Asia Pacific Journal of Innovation and Entrepreneurship, 11(2), 159-170.

Renzulli, L. A., Aldrich, H., dan Moody, J. (2000). Family Matters: Gender, Networks, and Entrepreneurial Outcomes. Social Forces, 79(2), 523-546.

Roundy, P. T., Harrison, D. A., Khavul, S., Pérez-Nordtvedt, L., dan McGee, J. E. (2018). Entrepreneurial alertness as a pathway to strategic decisions and organizational performance. Strategic Organization, 16(2), 192-226.

Rusli, R. H. (2017). Women Entrepreneurship in Malaysia.

Sexton, D. L., dan Bowman-Upton, N. (1990). Female and male entrepreneurs: Psychological characteristics and their role in gender-related discrimination. Journal of Business Venturing, 5(1), 29-36.

Shane, S. (2003). A general theory of entrepreneurship: The individual-opportunity nexus. Edward Elgar Publishing. ISBN 9781843769965.

Shane, S., dan Venkataraman, S. (2000). The promise of entrepreneurship as a field of research. Academy of Management Review, 25(1), 217-226.

Shapero, A., dan Sokol, L. (1982). The social dimensions of entrepreneurship. Encyclopedia of Entrepreneurship,72-90, Englewood Cliffs, NJ : Prentice-Hall, ISBN 0-13-275826-1.

Sharafizad, J. (2016). Women business owners' start-up motivations and network content. Journal of Small Business and Enterprise Development, 23(2), 590-610.

Shastri, S. (2019). Motivations and challenges of women entrepreneurs. International Journal of Sociology and Social Policy, 39(5/6), 338-355.

Shaver, K., dan Scott, L. R. (1991). Person, process, choice: The psychology of new venture creation. Entrepreneurship Theory and Practice, 27.

Sirmon, D. G., Gove, S., dan Hitt, M. A. (2008). Resource management in dyadic competitive rivalry: The effects of resource bundling and deployment. Academy of Management Journal, 51(5), 919-935.

Solesvik, M. (2019). Motivation of female entrepreneurs: A cross-national study. Journal of Small Business and Enterprise Development, 26(5), 684-705.

Sparrow, P. R., dan Makram, H. (2015). What is the value of talent management? Building valuedriven processes within a talent management architecture. Human resource management review, 25(3), 249-263.

Steier, L. (2007). New ventures creation and organization: A familial sub-narrative. Journal of business Research, 60, 1099-1107.

Sundin, E., dan Holmquist, C. (2006). Women as entrepreneurs in Sweden: Conclusions from a 
survey.

Talib, A., Yusof, M. N., Zan, Z. M., dan Ngah, K. (2017). E-Bisnes, pemangkin penyertaan kaum wanita dalam keusahawanan luar bandar. Journal of Advanced Research in Business and Management Studies, 9(1), 54-66.

Tanusia, A., Marthandan, G., dan Subramaniam, I. D. (2016). Economic empowerment of malaysian women through entrepreneurship: Barriers and enablers [Article]. Asian Social Science, 12(6), 81-94.

Thapa, A. (2015). Determinants of microenterprise performance in Nepal. Small Business Economics, 45(3), 581-594.

Waqar, A., Jamil, M., dan Fadzil, A. F. M. (2020). Comprehensive review of social entrepreneurship: Developing the conceptual framework for describing the phenomenon of social new venture creation. International Journal of Scientific and Technology Research, 9(4), 1987-1995.

Watson, J. (2002). Comparing the performance of male-and female-controlled businesses: Relating outputs to inputs. Entrepreneurship Theory and Practice, 26(3), 91-100.

Zainol Noor, R. (2018). Entrepreneurial competency, competitive advantage and performance of informal women micro-entrepreneurs in Kelantan, Malaysia. Journal of Enterprising Communities: People and Places in the Global Economy, 12(3), 299-321.

Zellweger, T., Sieger, P., dan Halter, F. (2011). Should I stay or should I go? Career choice intentions of students with family business background. Journal of Business Venturing, 26(5), 521-536.

Zisser, M. R., Johnson, S. L., Freeman, M. A., dan Staudenmaier, P. J. (2019). The relationship between entrepreneurial intent, gender and personality. Gender in Management: An International Journal, 34(8), 665-684. 